\author{
Piotr Kozak* \\ Uniwersytet Mikołaja Kopernika w Toruniu
}

\title{
KOSZTY DZIAKALNOŚCI BADAWCZO-ROZWOJOWEJ W ŚWIETLE PRZEPISÓW USTAWY O RACHUNKOWOŚCI I MIĘDZYNARODOWEGO STANDARDU RACHUNKOWOŚCI NR 38 WARTOŚCI NIEMATERIALNE
}

Słowa kluczowe: badania i rozwój, innowacja, koszty działalności badawczo-rozwojowej, rachunek kosztów, rozliczenia międzyokresowe kosztów, wartości niematerialne i prawne.

\begin{abstract}
Abstrakt: W artykule poddano krytycznej analizie sposób ewidencji i prezentacji informacji o kosztach działalności badawczo-rozwojowej, będących integralną częścią działalności innowacyjnej, wynikający ze stosowania do celów sprawozdawczych przepisów ustawy o rachunkowości i Międzynarodowego Standardu Rachunkowości nr 38 Wartości niematerialne.
\end{abstract}

\section{COSTS OF RESEARCH AND DEVELOPMENT IN THE VIEW OF THE ACCOUNTING ACT

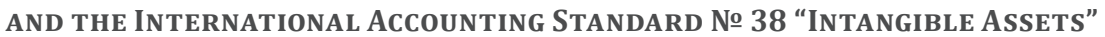

Keywords: cost accounting, deferred costs, innovation, intangible assets, research and development, R\&D costs.

Abstract: The article is a critical analysis of the evidence and the presentation of the costs information of research and development as an integral part of innovation, resulting from the application for the purposes of the reporting rules of the Accounting Act and International Accounting Standard 38 Intangible Assets.

Translated by Piotr Kozak

Data wpłynięcia: 22.11.2012; data zaakceptowania: 25.02.2013.

* Dane kontaktowe: piotr.kozak@uni.torun.pl, Katedra Rachunkowości, Wydział Nauk Ekonomicznych i Zarządzania, Uniwersytet Mikołaja Kopernika, ul. Gagarina 13a, 87-100 Toruń, tel. 566114779. 


\section{WSTĘP}

Jednym z celów zarządzania przedsiębiorstwem jest zdobycie przewagi konkurencyjnej. Osiągnięcie tego celu umożliwiają między innymi innowacje. Jednak aby przyniosły one zamierzone efekty, zarządzanie nimi musi opierać się na rzetelnych informacjach, w tym przede wszystkim na kosztach, które nierzadko stanowią jedno z głównych kryteriów selekcji projektów innowacyjnych. Z tego powodu znaczenia nabiera sposób ewidencji kosztów projektów innowacyjnych w księgach rachunkowych przedsiębiorstw, które są głównym źródłem informacji o nich.

Celem artykułu jest omówienie sposobów ewidencji kosztów prac badawczych i rozwojowych w kontekście wpływu na wycenę tych kosztów do celów decyzyjnych.

W artykule wykorzystano analizę krytyczną jako narzędzie oceny sposobu ewidencji i prezentacji do celów sprawozdawczych kosztów działalności innowacyjnej w zakresie prac badawczo-rozwojowych według ustawy o rachunkowości (1994) i Międzynarodowego Standardu Rachunkowości nr 38 Wartości niematerialne (Rozporządzenie Komisji 2008).

\section{ZWIĄZEK DZIAŁALNOŚCI BADAWCZO-ROZWOJOWEJ Z DZIAŁALNOŚCIĄ INNOWACYJNĄ}

Innowacyjność jest rozumiana jako „rzecz nowo wprowadzona, nowość” (Słownik wyrazów obcych 2012). Przytoczone wyjaśnienie jest w swojej istocie bardzo ogólne i oznacza jedynie, że innowacją może być coś, czego jeszcze do tej pory nie było. Idąc tym tokiem rozumowania, za innowację można uznać wynalazek w zakresie przedmiotów technicznych i w konsekwencji występowanie innowacji znacznie ograniczyć. Inaczej pojęcie to zdefiniowano w Podręczniku Oslo (2005: 48)ํㅣㄹ , według którego innowacja „to wdrożenie nowego lub znacząco udoskonalonego produktu (wyrobu lub usługi) lub procesu, nowej metody

${ }^{1}$ Przygotowany wspólnie przez OECD i Komisję Europejską, jest wynikiem współpracy w ramach Grupy Roboczej OECD Ekspertów Krajowych ds. Wskaźników Naukowo-Technicznych (OECD Working Party of National Experts on Science and Technology Indicators, NESTI), Grupy Roboczej Eurostatu ds. Statystyki Nauki, Techniki i Innowacji (WPSTI) oraz innych ekspertów zewnętrznych. Podręcznik Oslo reguluje zasady gromadzenia i interpretacji danych z zakresu innowacji w celu zapewnienia międzynarodowej porównywalności danych. 
marketingowej lub nowej metody organizacyjnej w praktyce gospodarczej, organizacji miejsca pracy lub stosunkach z otoczeniem". W stosunku do poprzedniej, definicja z Podręcznika Oslo wprowadza trzy istotne zmiany. Po pierwsze, za innowację uznaje się przedmioty, wartości niematerialne czy procesy, które wdrożono, tzn. które wprowadzono w życie, zastosowano, zrealizowano. Nie wystarczy wynaleźć czy opracować i opisać. Należy jeszcze udowodnić przydatność przez wdrożenie. W przypadku nowego produktu wdrożeniem będzie jego wyprodukowanie, w tym także partii próbnej. Po drugie, innowacją jest nowość, ale dla przedsiębiorstwa, które je wdraża. Oznacza to, że nie musi być ona nowością w pełnym tego słowa znaczenia, czyli nie musi być wynalazkiem. To, co jest nowością dla jednego przedsiębiorstwa, nie musi być tym samym dla innego. Po trzecie, za innowację uznaje się proces, którego efektem jest wdrożenie, a nie przedmiot wdrożenia. Ten proces obejmuje szereg działań o charakterze technicznym, organizacyjnym, finansowym czy marketingowym.

Do działań, których celem jest wdrożenie innowacji, zalicza się także działalność badawczo-rozwojową, którą w Podręczniku Frascati (2002: 34)² określa się jako „pracę twórczą podejmowaną w sposób systematyczny w celu zwiększenia zasobów wiedzy, w tym wiedzy o człowieku, kulturze i społeczeństwie, oraz wykorzystanie tych zasobów wiedzy do tworzenia nowych zastosowann". Podstawowym celem działalności badawczo-rozwojowej jest pozyskanie nowej wiedzy i doprowadzenie do sytuacji, w której będzie można ją wykorzystać do wdrażania innowacji.

Z powyższych rozważań wynika, że innowacja jest pierwszym zastosowaniem nowego pomysłu czy wynalazku, chociaż nie jest pierwszym etapem tego procesu. Wyodrębnienie poszczególnych etapów dokonuje się ze względu na ich specyfikę, przedmiot, przebieg czy miejsce powstawania. W literaturze przedmiotu trudno doszukać się jednolitego ujęcia etapów procesu innowacji, co wynika z jednostkowego podejścia do tego tematu. Przedstawione na schemacie 1 etapy procesu innowacji uwzględniają trzy podstawowe działania przy założeniu, że wdrożenie kończy proces innowacji i tym samym nie uwzględnia takich dodatkowych działań, jak upowszechnianie innowacji, jej doskonalenie

2 Nazwa podręcznika pochodzi od włoskiej miejscowości Frascati, w której w 1963 r. odbyło się spotkanie ekspertów specjalizujących się w zagadnieniach statystyki działalności badawczo-rozwojowej. Organizatorem spotkania była OECD. Podręcznik Frascati jest standardem dla badań statystycznych sfery badawczo-rozwojowej w państwach członkowskich OECD i spoza tej organizacji. 
przez racjonalizację czy kontrolę procesu innowacji, które nie należą do opisywanego w tym artykule tematu.

Schemat 1. Podstawowe etapy procesu innowacji

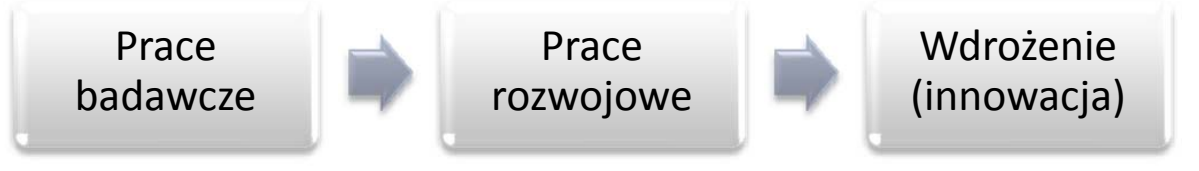

Źr ó d ł o : opracowanie własne na podstawie: Baruk 1992: 46-47.

Spośród trzech podstawowych etapów procesu innowacji do zakresu działalności badawczo-rozwojowej zalicza się dwa pierwsze, z tym że w przypadku prac badawczych dokonuje się ich dalszego podziału na prace podstawowe i stosowane (Pomykalski 2001a: 95).

Badaniami podstawowymi określa się działania, których celem jest pozyskanie nowego, oryginalnego i niepowtarzalnego dla przedsiębiorstwa zasobu wiedzy. Ich cechą jest to, że nie są one podejmowane w związku z realizacją jakiegokolwiek projektu, którego celem jest wdrożenie innowacji. Do badań podstawowych zalicza się badania naukowe, skutkujące sformułowaniem nowych tez, koncepcji czy teorii naukowych. Są one zwykle podejmowane w związku z realizacją zainteresowań pracowników instytucji naukowych. Mogą być także inspirowane przez przemysł. W takim przypadku są one nazywane badaniami podstawowymi skierowanymi (Czupiał 1994: 11).

Badaniami stosowanymi są działania podejmowane w celu zdobycia nowej wiedzy naukowej lub technicznej, niezbędnej do rozwiązania konkretnego problemu. Tym różnią się od badań podstawowych, że mają cel praktyczny. Są odpowiedzią na zapotrzebowanie rynkowe. Podejmując tego typu badania, zakłada się możliwość powstania wynalazku lub innego wytworu myśli ludzkiej chronionego prawem (Czupiał 1994: 11).

Prace rozwojowe polegają na praktycznym zastosowaniu wiedzy, w tym wynalazków, w celu eksperymentalnego wy tworzenia nowego lub udoskonalonego produktu czy technologii, które ma miejsce przed rozpoczęciem produkcji seryjnej lub zastosowaniem (Czupiał 1994: 12). Prace rozwojowe są podejmowane w celu praktycznego wykorzystania wynalazku w praktyce. Efektem prac rozwojowych jest skonstruowanie modelu lub prototypu, opracowanie 
dokumentacji technicznej, analiza rynku ze względu na wielkość popytu oraz ze względu na możliwości kooperantów, opracowanie planów finansowych ze względu na rentowność oraz możliwość pozyskania źródeł finansowania. Prace rozwojowe są wspólnym wysiłkiem pracowników naukowych i pracowników przedsiębiorstwa, zamierzającego wdrożyć innowację, co wynika z konieczności przystosowania wynalazku do możliwości technicznych przedsiębiorstwa.

Każda z wyżej wymienionych aktywności, stanowiących istotę działalności badawczo-rozwojowej, generuje koszty, których ponoszenie jest szczególnie ryzykowne dla przedsiębiorstw ze względu na niepewność powodzenia wdrożenia efektów tych prac. Przykładowe koszty działalności badawczo-rozwojowej zaprezentowano w tabeli 1.

Tabela 1. Przykładowe koszty działalności badawczo-rozwojowej

\begin{tabular}{|c|c|}
\hline $\begin{array}{c}\text { Koszty prac badawczych } \\
\text { (podstawowych i stosowanych) }\end{array}$ & Koszty prac rozwojowych \\
\hline \multicolumn{2}{|l|}{$\begin{array}{l}\text { - amortyzacja, } \\
\text { - ekspertyzy, } \\
\text { - naprawy, } \\
\text { - usługi obce, } \\
\text { - utrzymanie biur, } \\
\text { - utrzymanie laboratoriów, } \\
\text { - wynagrodzenia z narzutami, } \\
\text { - zużycie materiałów, } \\
\text { - zużycie narzędzi }\end{array}$} \\
\hline $\begin{array}{l}\text { - granty i stypendia naukowe, } \\
\text { - publikacje naukowe, } \\
\text { - staże naukowe, } \\
\text { - szkolenie kadr, } \\
\text { - udział w konferencjach. }\end{array}$ & $\begin{array}{l}\text { - amortyzacja, } \\
\text { - badania uzupełniające, } \\
\text { - ekspertyzy, } \\
\text { - eksperymentalne wytworzenie, } \\
\text { - marketingowa analiza rynku, } \\
\text { - ochrona patentowa, } \\
\text { - opracowanie prototypu, } \\
\text { - prace konstrukcyjne, } \\
\text { - prace projektowe, } \\
\text { - inne prawa ochronne, } \\
\text { - przeszkolenie pracowników, } \\
\text { - przygotowanie dokumentacji, } \\
\text { - sprawdzenie prototypu, } \\
\text { - ulepszenie prototypu. }\end{array}$ \\
\hline
\end{tabular}

Źr ó dło : opracowanie własne na podstawie: Cholewicka-Goździk 1984: 90; Podręcznik Frascati 2002 , rozdz. 6 .

Analiza kosztów wymienionych w tabeli 1 potwierdza odmienność prac badawczych i rozwojowych. Jeżeli pierwsze z nich skupiają się głównie na pracy naukowej, drugie są ukierunkowane na praktyczne jej wykorzystanie. Nie 
zmienia tego fakt, że część kosztów jest wspólnych zarówno dla prac badawczych, jak i rozwojowych.

W celu wdrożenia innowacji przedsiębiorstwa nie muszą przechodzić przez każdy z etapów procesu. Część przedsiębiorstw, ze względu na stopień trudności, niepewności i wysokich kosztów zleca ich wykonanie lub nabywa od zewnętrznych podmiotów licencje, patenty bądź inne wytwory myśli ludzkiej strzeżone prawami ochronnymi.

\section{KoSZTY DZIAEALNOŚCI BADAWCZO-ROZWOJOWEJ WEDEUG USTAWY O RACHUNKOWOŚCI}

Ustawa o rachunkowości traktuje koszty działalności badawczo-rozwojowej w sposób fragmentaryczny. Przemilcza zupełnie kwestię kosztów działalności badawczej, o kosztach działalności rozwojowej wspomina zaś, bez podania definicji, w kontekście wyłącznie zakończonych prac.

Zgodnie z treścią art. 3 ust. 1 pkt 14 przedsiębiorstwa zaliczają koszty zakończonych prac rozwojowych do wartości niematerialnych i prawnych, jeżeli zostaną spełnione warunki, o których mowa w art. 33 ust. 2. Z artykułu tego wynika, że „koszty zakończonych prac rozwojowych prowadzonych przez jednostkę na własne potrzeby, poniesione przed podjęciem produkcji lub zastosowaniem technologii, zalicza się do wartości niematerialnych i prawnych, jeżeli:

1. produkt lub technologia wytwarzania są ściśle ustalone, a dotyczące ich koszty prac rozwojowych wiarygodnie określone;

2. techniczna przydatność produktu lub technologii została stwierdzona i odpowiednio udokumentowana i na tej podstawie jednostka podjęła decyzję o wytwarzaniu tych produktów lub stosowaniu technologii;

3. koszty prac rozwojowych zostaną pokryte, według przewidywań, przychodami ze sprzedaży tych produktów lub zastosowania technologii".

Jeżeli zostaną spełnione łącznie warunki określone w art. 33 ust. 2 ustawy, koszty zakończonych prac rozwojowych zostaną zaliczone do wartości niematerialnych i prawnych, a maksymalny okres ich amortyzowania, zgodnie $\mathrm{z}$ art. 33 ust. 3 , wyniesie 5 lat.

Z kolei, jeżeli nie zostanie spełniony jeden z warunków art. 33 ust. 2 ustawy, koszty zakończonych prac rozwojowych zostaną wpisane w ciężar pozostałych kosztów operacyjnych.

Odnośnie do kosztów prac badawczych, o których ustawa o rachunkowości nie wspomina, z pomocą przychodzą przepisy art. 10 ust. 3 ustawy, z których 
wynika, że „w sprawach nieuregulowanych przepisami ustawy, przyjmując zasady (politykę) rachunkowości, jednostki mogą stosować krajowe standardy rachunkowości wydane przez Komitet Standardów Rachunkowości. W przypadku braku odpowiedniego standardu krajowego jednostki, inne niż wymienione w art. 2 ust. 3, mogą stosować MSR". Ponieważ żaden z krajowych standardów nie odnosi się do prac badawczo-rozwojowych, jedynym wyjściem pozostaje skorzystać z rozwiązań zawartych w Międzynarodowym Standardzie Rachunkowości nr 38 Wartości niematerialne.

\section{KOSZTY DZIAŁALNOŚCI BADAWCZO-ROZWOJOWEJ WEDEUG MIĘDZYNARODOWEGo STANDARDU RACHUNKOWOŚCI NR 38 WARTOŚCI NIEMATERIALNE}

W Międzynarodowym Standardzie Rachunkowości nr 38 Wartości niematerialne - zgodnie z $§ 5$ - koszty działalności badawczo-rozwojowej określa się ogólnie jako koszty działalności ukierunkowanej na rozwój wiedzy. Główny cel tej działalności, polegający na pozyskaniu nowej wiedzy, tłumaczy kwalifikowanie efektów tych prac do wartości niematerialnych i prawnych, nawet jeżeli ta działalność kończy się wytworzeniem prototypu, mającego atrybuty aktywa materialnego.

Międzynarodowy Standard Rachunkowości nr 38 Wartości niematerialne w odróżnieniu od ustawy o rachunkowości przytacza również definicje oddzielnie dla prac badawczych, jak i rozwojowych. Prace badawcze - zgodnie z $§ 8$ - definiuje się jako nowatorskie i zaplanowane poszukiwanie rozwiązań podjęte z zamiarem zdobycia i przyswojenia nowej wiedzy naukowej i technicznej.

Koszty prac badawczych - zgodnie z $§ 54$ - podlegają w całości zaliczeniu do kosztów okresu, w jakim zostały one poniesione. Nie są w związku z tym aktywowane w bilansie jako wartości niematerialne i prawne. Uzasadnia się to tym, że na etapie prac badawczych przedsiębiorstwo nie jest w stanie określić prawdopodobieństwa oraz skali osiągniętych w przyszłości korzyści. W § 56 wymieniono prace badawcze, do których zaliczono:

1. działania zmierzające do zdobycia nowej wiedzy;

2. poszukiwanie, ocenę i końcową selekcję sposobu wykorzystania rezultatów prac badawczych lub wiedzy innego rodzaju;

3. poszukiwanie alternatywnych materiałów, urządzeń, produktów, procesów, systemów lub usług oraz 
4. formułowanie, projektowanie, ocenę i końcową selekcję nowych lub udoskonalonych materiałów, urządzeń, produktów, procesów, systemów lub usług.

Schemat 2. Ewidencja kosztów prac badawczych na własne potrzeby

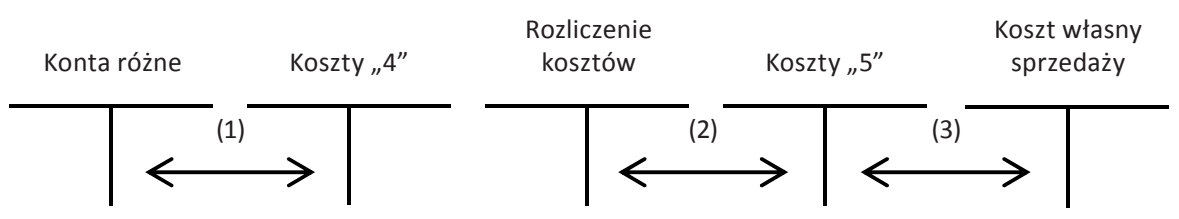

(1) Poniesienie kosztów rodzajowych w związku z pracami badawczymi.

(2) Księgowanie kosztów prac rozwojowych ze względu na miejsce ich poniesienia.

(3) Obciążenie kosztów bieżącego okresu.

Ź r ó d ło : opracowanie własne.

Z kolei prace rozwojowe - zgodnie z § 8 - są definiowane jako „praktyczne zastosowanie odkryć badawczych lub też osiągnięć innej wiedzy w planowaniu lub projektowaniu produkcji nowych lub znacznie udoskonalonych materiałów, urządzeń, produktów, procesów technologicznych, systemów lub usług, które ma miejsce przed rozpoczęciem produkcji seryjnej lub zastosowaniem".

Koszty prac rozwojowych - zgodnie z § 57 - ujmuje się w wartościach niematerialnych i prawnych, jeżeli przedsiębiorstwo udowodni:

1. możliwość, z technicznego punktu widzenia, ukończenia składnika wartości niematerialnych tak, aby nadawał się do użytkowania lub sprzedaży;

2. zamiar ukończenia składnika wartości niematerialnych oraz jego użytkowania lub sprzedaży;

3. zdolność do użytkowania lub sprzedaży składnika wartości niematerialnych;

4. sposób, w jaki składnik wartości niematerialnych będzie wytwarzał prawdopodobne przyszłe korzyści ekonomiczne; między innymi jednostka może udowodnić istnienie rynku na produkty powstające dzięki składnikowi wartości niematerialnych lub na sam składnik bądź - jeśli składnik ma być użytkowany przez jednostkę - użyteczność składnika wartości niematerialnych; 
5. dostępność stosownych środków technicznych, finansowych i innych, które mają służyć ukończeniu prac rozwojowych oraz użytkowaniu lub sprzedaży składnika wartości niematerialnych;

6. możliwość wiarygodnego ustalenia nakładów poniesionych w czasie prac rozwojowych, które można przyporządkować temu składnikowi wartości niematerialnych.

W paragrafie 59 wymieniono prace rozwojowe, do których zaliczono:

1. projektowanie, wykonanie i testowanie prototypów i modeli doświadczalnych (przed ich wdrożeniem do produkcji seryjnej lub użytkowania);

2. projektowanie narzędzi, przyrządów do obróbki, form i matryc z wykorzystaniem nowej technologii;

3. projektowanie, wykonanie i funkcjonowanie linii pilotażowej, której wielkość nie umożliwia prowadzenia ekonomicznie uzasadnionej produkcji przeznaczonej na sprzedaż;

4. projektowanie, wykonanie i testowanie wybranych rozwiązań w zakresie nowych lub udoskonalonych materiałów, urządzeń, produktów, procesów, systemów lub usług.

Schemat 3. Ewidencja kosztów zakończonych prac rozwojowych na własne potrzeby (rozpoczęte i zakończone w bieżącym okresie)

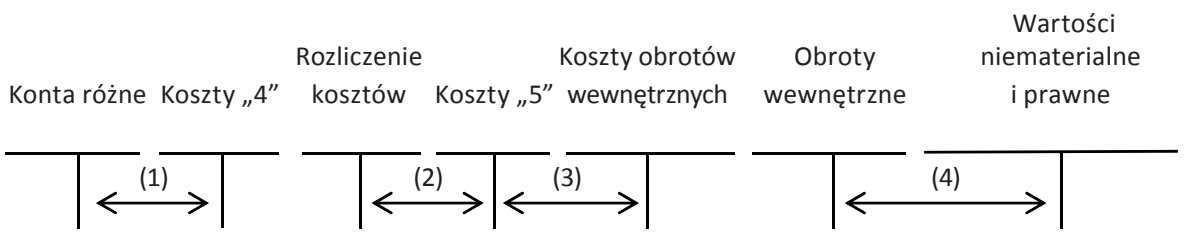

(1) Poniesienie kosztów rodzajowych w związku z pracami rozwojowymi.

(2) Księgowanie kosztów prac rozwojowych ze względu na miejsce ich poniesienia.

(3) Przeniesienie kosztów prac rozwojowych poza krąg kosztów.

(4) Rozliczenie zakończonych prac rozwojowych na wartości niematerialne i prawne.

Źr ó dło: opracowanie własne. 
Schemat 4. Ewidencja kosztów zakończonych prac rozwojowych na własne potrzeby (rozpoczęte w poprzednim i zakończone w bieżącym okresie)

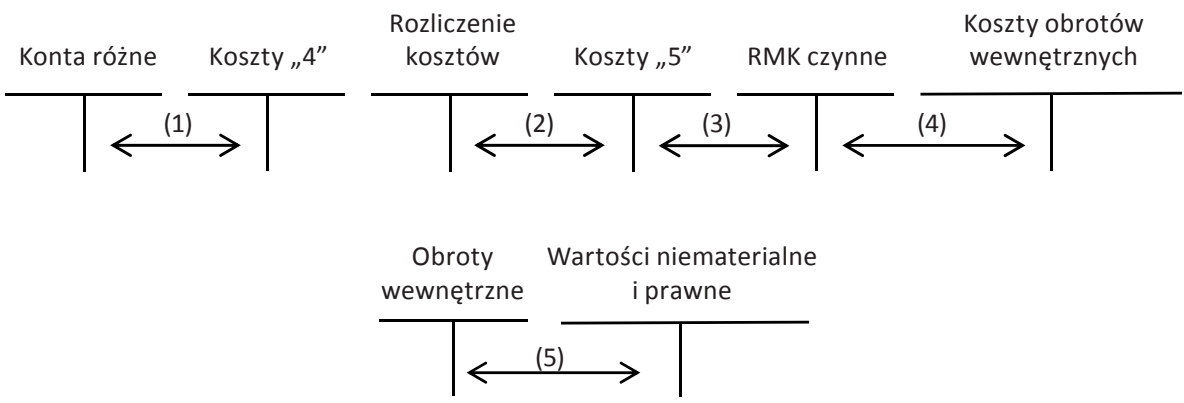

(1) Poniesienie kosztów rodzajowych w związku z pracami rozwojowymi.

(2) Księgowanie kosztów prac rozwojowych ze względu na miejsce ich poniesienia.

(3) Przeniesienie kosztów prac rozwojowych na rozliczenia międzyokresowe kosztów czynne.

(4) Przeniesienie kosztów prac rozwojowych poza krąg kosztów.

(5) Rozliczenie zakończonych prac rozwojowych na wartości niematerialne i prawne.

Źr ó d ło : opracowanie własne.

Schemat 5. Ewidencja kosztów zakończonych prac rozwojowych na własne potrzeby bez efektu (rozpoczęte i zakończone w bieżącym okresie)

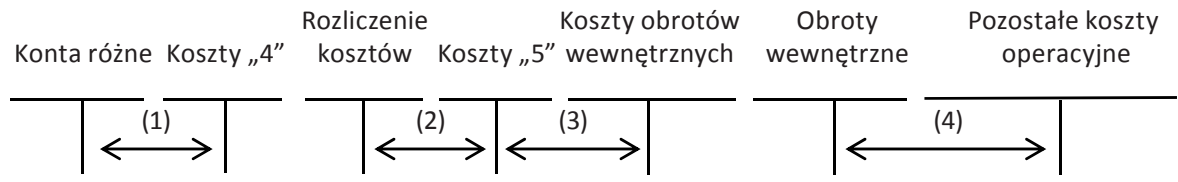

(1) Poniesienie kosztów rodzajowych w związku z pracami rozwojowymi.

(2) Księgowanie kosztów prac rozwojowych ze względu na miejsce ich poniesienia.

(3) Przeniesienie kosztów prac rozwojowych poza krąg kosztów.

(4) Rozliczenie zakończonych prac rozwojowych w ciężar pozostałych kosztów operacyjnych.

Źr ó dło : opracowanie własne. 
Schemat 6. Ewidencja kosztów zakończonych prac rozwojowych na własne potrzeby bez efektu (rozpoczęte w poprzednim i zakończone w bieżącym okresie)

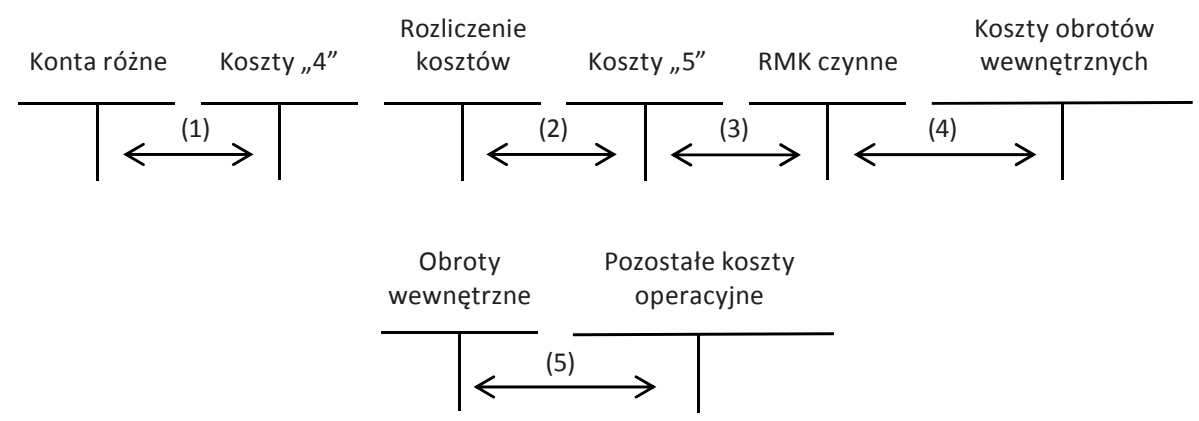

(1) Poniesienie kosztów rodzajowych w związku z pracami rozwojowymi.

(2) Księgowanie kosztów prac rozwojowych ze względu na miejsce ich poniesienia.

(3) Przeniesienie kosztów prac rozwojowych na rozliczenia międzyokresowe kosztów czynne.

(4) Przeniesienie kosztów prac rozwojowych poza krąg kosztów.

(5) Rozliczenie zakończonych prac rozwojowych w ciężar pozostałych kosztów operacyjnych.

Źr ó dło : opracowanie własne.

Warianty ewidencji kosztów prac rozwojowych ze względu na czas ich realizacji oraz efekt końcowy można przedstawić także na układzie współrzędnych, tak jak na schemacie 7.

Prezentacja kosztów prac rozwojowych na układzie współrzędnych, inaczej niż ewidencja na kontach, uwypukla ryzyko związane z realizacją tego typu przedsięwzięć. Ponadto, usytuowanie punktów początkowych prac rozwojowych ponad osią czasu oznacza, że wszystkie one są realizowane w celu uzyskania zamierzonego efektu, którego celem jest przyrost stanu majątku lub inne korzyści. Jedynie nieprzewidziane zdarzenia mogą doprowadzić do wpisania poniesionych nakładów w ciężar pozostałych kosztów operacyjnych. 
Schemat 7. Koszty prac rozwojowych ze względu na czas ich trwania i efekt

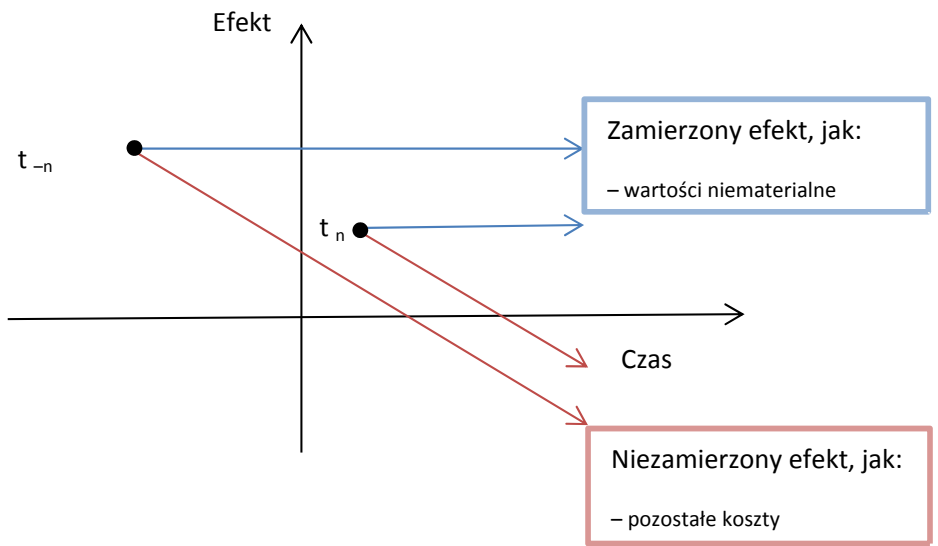

gdzie: $\quad t_{n}$ - rozpoczęcie prac rozwojowych w bieżącym okresie,

$t_{-n}$ - rozpoczęcie prac rozwojowych w poprzednich okresach.

Źr ó dło: opracowanie własne.

W tabeli 2 zebrano wybrane regulacje dotyczące działalności badawczo-rozwojowej.

Tabela 2. Wybrane regulacje w zakresie prac działalności badawczo-rozwojowej

\begin{tabular}{|c|c|c|c|}
\hline & $\begin{array}{l}\text { Ustawa } \\
\text { o rachunkowości }\end{array}$ & $\begin{array}{c}\text { Krajowe } \\
\text { Standardy } \\
\text { Rachunko- } \\
\text { wości }\end{array}$ & $\begin{array}{c}\text { Międzynarodowe } \\
\text { Standardy Rachunkowości }\end{array}$ \\
\hline $\begin{array}{l}\text { Prace } \\
\text { badawcze }\end{array}$ & brak & brak & $\begin{array}{l}\text { 1. Prace badawcze definiuje się jako no- } \\
\text { watorskie i zaplanowane poszukiwanie } \\
\text { rozwiązań podjęte z zamiarem zdobycia } \\
\text { i przyswojenia nowej wiedzy naukowej } \\
\text { i technicznej (§ 8). } \\
\text { 2. Jednostka, która nie jest w stanie od- } \\
\text { dzielić etapu prac badawczych od etapu } \\
\text { prac rozwojowych przedsięwzięcia pro- } \\
\text { wadzącego do wytworzenia składnika } \\
\text { wartości niematerialnych, traktuje na- } \\
\text { kłady na to przedsięwzięcie, jak gdyby } \\
\text { zostały poniesione wyłącznie na etapie } \\
\text { prac badawczych (§ 53). } \\
\text { 3. Nakłady poniesione na prace badawcze } \\
\text { (lub na realizację etapu prac badaw- } \\
\text { czych przedsięwzięcia prowadzonego } \\
\text { we własnym zakresie) ujmuje się w kosz- } \\
\text { tach w momencie ich poniesienia (§ } 54 \text { ). }\end{array}$ \\
\hline
\end{tabular}




\begin{tabular}{|c|c|c|c|}
\hline & $\begin{array}{l}\text { Ustawa } \\
\text { o rachunkowości }\end{array}$ & $\begin{array}{c}\text { Krajowe } \\
\text { Standardy } \\
\text { Rachunko- } \\
\text { wości }\end{array}$ & $\begin{array}{c}\text { Międzynarodowe } \\
\text { Standardy Rachunkowości }\end{array}$ \\
\hline $\begin{array}{l}\text { Prace } \\
\text { rozwojowe }\end{array}$ & $\begin{array}{l}\text { 1. Do wartości niematerialnych i praw- } \\
\text { nych zalicza się również nabytą wartość } \\
\text { firmy oraz koszty zakończonych prac } \\
\text { rozwojowych (art. } 3 \text { ust. 1). } \\
\text { 2. Koszty zakończonych prac rozwojo- } \\
\text { wych prowadzonych przez jednostkę } \\
\text { na własne potrzeby, poniesione przed } \\
\text { podjęciem produkcji lub zastosowa- } \\
\text { niem technologii, zalicza się do warto- } \\
\text { ści niematerialnych i prawnych, jeżeli: } \\
\text { - produkt lub technologia wytwarza- } \\
\text { nia są ściśle ustalone, a dotyczące } \\
\text { ich koszty prac rozwojowych wiary- } \\
\text { godnie określone; } \\
\text { - techniczna przydatność produktu } \\
\text { lub technologii została stwierdzona } \\
\text { i odpowiednio udokumentowana } \\
\text { i na tej podstawie jednostka podjęła } \\
\text { decyzję o wytwarzaniu tych produk- } \\
\text { tów lub stosowaniu technologii; } \\
\text { - koszty prac rozwojowych zostaną } \\
\text { pokryte, według przewidywań, przy- } \\
\text { chodami ze sprzedaży tych produk- } \\
\text { tów lub zastosowania technologii } \\
\text { (art. } 33 \text { ust. 2). } \\
\text { 3. Okres dokonywania odpisów amorty- } \\
\text { zacyjnych od kosztów zakończonych } \\
\text { prac rozwojowych nie może przekra- } \\
\text { czać } 5 \text { lat (art. } 33 \text { ust. 3). }\end{array}$ & brak & $\begin{array}{l}\text { 1. Prace rozwojowe są praktycznym zasto- } \\
\text { sowaniem odkryć badawczych lub też } \\
\text { osiągnięć innej wiedzy w planowaniu } \\
\text { lub projektowaniu produkcji nowych lub } \\
\text { znacznie udoskonalonych materiałów, } \\
\text { urządzeń, produktów, procesów tech- } \\
\text { nologicznych, systemów lub usług, które } \\
\text { ma miejsce przed rozpoczęciem produk- } \\
\text { cji seryjnej lub zastosowaniem (§ 8). } \\
\text { 2. W niektórych przypadkach jednostka } \\
\text { ponosi nakłady w celu osiągnięcia przy- } \\
\text { szłych korzyści ekonomicznych, ale nie } \\
\text { nabywa ani nie tworzy żadnego składni- } \\
\text { ka wartości niematerialnych lub innego } \\
\text { składnika aktywów, który mógłby zostać } \\
\text { ujęty. W takich przypadkach nakłady są } \\
\text { ujmowane w ciężar rachunku zysków } \\
\text { istratw momencie ich poniesienia (§69). }\end{array}$ \\
\hline
\end{tabular}

Źr ó d ło : opracowanie własne.

Podsumowując, należy stwierdzić, że ocena systemu ewidencyjnego kosztów prac badawczo-rozwojowych, wynikającego ze stosowania przepisów ustawy o rachunkowości i Międzynarodowego Standardu Rachunkowości nr 38 Wartości niematerialne, jest jednoznacznie negatywna. Sposób ujmowania kosztów w ewidencji nie pozwala na prawidłową wycenę potencjalnych wartości niematerialnych i prawnych z powodu księgowania kosztów prac badawczych bezpośrednio w koszty działalności bez względu na efekt. Tymczasem prace te są podejmowane niejednokrotnie w związku z realizacją projektów innowacyjnych, których prace badawcze stanowią często pierwszy i niezwykle ważny etap. 


\section{PREZENTACJA I WYCENA KoSZTóW DZIAŁALNoŚCI BADAWCZO-ROZWOJOWEJ}

Na podstawie przepisów Międzynarodowego Standardu Rachunkowości nr 38 Wartości niematerialne koszty prac badawczych ujmuje się w kosztach okresu, w którym zostały poniesione, przez co kształtują one wynik ze sprzedaży lub z działalności operacyjnej. Z kolei koszty prac rozwojowych wykazuje się w bilansie w wartościach niematerialnych i prawnych. Ustawa o rachunkowości, w zakresie kosztów prac rozwojowych, stosuje podobne rozwiązania jak w MSR nr 38, a o kosztach prac działalności badawczej nie wspomina. Mając na uwadze treść art. 10 ustawy oraz brak krajowych standardów w tym zakresie, podmioty sporządzające sprawozdanie finansowe zgodnie z ustawą o rachunkowości i międzynarodowymi standardami rachunkowości będą podobnie ewidencjonować i prezentować koszty działalności badawczo-rozwojowej. Powstaje w związku z tym pytanie, czy ta unifikacja w regulacjach krajowych i międzynarodowych oznacza, że przyjęte rozwiązania są najlepsze z możliwych?

Dokładniejsza analiza przytoczonych wyżej rozwiązań może jednak wzbudzać uzasadnione wątpliwości, które zostaną wyjaśnione na przykładzie patentu. Patent jest prawem majątkowym i rezultatem prac rozwojowych. Przedsiębiorstwo może wejść w posiadanie wiedzy usankcjonowanej patentem na dwa sposoby. Może ją uzyskać, prowadząc prace badawcze i rozwojowe we własnym zakresie (lub tylko rozwojowe), albo kupić od innego podmiotu. W pierwszym przypadku powstaną koszty o wartości przypadającej na prace badawcze oraz wartość niematerialna i prawna w wartości odpowiadającej nakładom na prace rozwojowe. W drugim przypadku przedsiębiorstwo wykaże tylko wartość niematerialną i prawną. Sposób pozyskania patentu nie determinuje sposobu jego wykorzystania, ale sposób jego wyceny - już tak. Księgowanie kosztów prac badawczych w ciężar kosztów okresu nabiera szczególnego znaczenia w przypadku, gdy przedsiębiorstwo prowadzi tego typu prace sporadycznie. Spowoduje to zniekształcenie wyniku finansowego w okresie trwania prac badawczych o koszty, które w przedsiębiorstwie występują okazjonalnie (wyjątkiem są ośrodki badawcze).

Rozwiązaniem, które nie wpływa na zniekształcenie wyniku finansowego, jest księgowanie kosztów prac badawczych, podobnie jak w praktyce gospodarczej z kosztami prac rozwojowych, na koncie rozliczeń międzyokresowych. Taki sposób księgowania jest uzasadniony, ponieważ przedsiębiorstwa, podejmując prace badawcze, liczą na efekty w postaci nowych rozwiązań. Zaliczanie kosztów tych prac w ciężar kosztów w trakcie ich prowadzenia wydaje się 
przedwczesne. W przypadku, gdy prace badawcze zakończą się bez efektu, obciążenie kosztów następowałoby w okresie, gdy przedsiębiorstwo ma o tym stuprocentową pewność.

Dzielenie prac na badawcze i rozwojowe w przypadku, gdy granica między nimi jest płynna, to działanie subiektywne. Szczególnie, jeżeli koszty tych prac są wysokie, istnieje ryzyko manipulowania wynikiem finansowym. Jeżeli koszty zaliczymy do prac badawczych, to nastąpi zmniejszenie wyniku finansowego, jeżeli zaliczymy do prac rozwojowych, mamy składnik aktywów, bez wpływu na wysokość wyniku finansowego w określonym przedziale czasu.

Odmienne, ze względu na sposób prezentacji, traktowanie kosztów prac badawczych i rozwojowych skutkuje wyceną wartości niematerialnych i prawnych lub innych aktywów w wartości niższej o wartość kosztów prac badawczych.

\section{ZAKOŃCZENIE}

Jednym z celów zarządzania przedsiębiorstwem jest zdobycie przewagi konkurencyjnej, którą realizuje się między innymi przez innowacje. Do sprawnego zarządzania innowacjami niezbędny jest dobrze funkcjonujący system ewidencyjny, generujący informacje o kosztach ich wprowadzania. System, który dostarczy kompleksowych danych do oceny poniesionych nakładów pod kątem efektywnego ich wykorzystania. Niestety, obecnie stosowane systemy ewidencyjne, regulowane przepisami ustawy o rachunkowości, jak i Międzynarodowego Standardu Rachunkowości nr 38 Wartości niematerialne, służą jednak przede wszystkim celom sprawozdawczym, a nie decyzyjnym. Bardzo dobrze widać to na przykładzie kosztów prac badawczo-rozwojowych, których sposób ewidencji i prezentacji nie ułatwia pozyskiwania użytecznych informacji o nich do celów decyzyjnych. Odczuwa się to szczególnie w przypadku, gdy prace badawcze są prowadzone w długim okresie. Z tego powodu wątpliwości budzi przede wszystkim bezpośrednie odnoszenie w koszty tych prac od momentu ich rozpoczęcia, aż do zakończenia, bez względu na efekt. Skutkuje to tym, że wycena wartości niematerialnej i prawnej zrealizowanej w wyniku prac rozwojowych nie obejmuje kosztów uprzednio prowadzonych prac badawczych. Inną kwestią pozostaje kwalifikacja kosztów do prac badawczych i rozwojowych, co przy wzajemnym przenikaniu się tych dwóch etapów procesu innowacyjnego może prowadzić do prób manipulowania wysokością wyniku finansowego. 


\section{IITERATURA}

Baruk J. (1992), Innowacje czynnikiem efektywnego rozwoju przedsiębiorstwa (aspekty ekonomiczno-organizacyjne), Wydawnictwo Uniwersytetu Marii Curie-Skłodowskiej, Lublin.

Cholewicka-Goździk K. (1984), Kompleksowa ocena jakości. Metoda, przykłady, Wydawnictwo Naukowe PWN, Warszawa.

Czupiał J. (red.) (1994), Ekonomika innowacji, Wydawnictwo Akademii Ekonomicznej im. Oskara Langego we Wrocławiu, Wrocław.

Międzynarodowy Standard Rachunkowości nr 38, Wartości niematerialne, [w:] Rozporządzenie Komisji (WE) nr 1126/2008 z dnia 3 listopada 2008 r. przyjmujące określone międzynarodowe standardy rachunkowości zgodnie z rozporządzeniem (WE) nr 1606/2002 Parlamentu Europejskiego i Rady, http://www.mf.gov.pl/ministerstwo-finansow/dzialalnosc/rachunkowosc/miedzynarodowe-standardy-rachunkowosci (dostęp 20.11.2012).

Podręcznik Frascati. Proponowane procedury standardowe dla badań statystycznych w zakresie działalności badawczo-rozwojowej (2002), OECD.

Podręcznik Oslo. Zasady gromadzenia i interpretacji danych dotyczących innowacji (2005), OECD, Eurostat.

Pomykalski A. (2001a), Innowacje, Wydawnictwo Politechniki Łódzkiej, Łódź 2001.

Pomykalski A. (2001b), Zarządzanie innowacjami, Wydawnictwo Naukowe PWN, Warszawa-Łódź.

Słownik wyrazów obcych, http://www.swo.pwn.pl/haslo.php?id=11855 (dostęp 20.11. 2012).

Ustawa z dnia 29 września 1994 r. o rachunkowości (Dz. U. 09.152.1223). 